\title{
Establishment and Characterization of a New Continuous Cell Line from Lutzomyia longipalpis (Diptera: Psychodidae) and its Susceptibility to Infections with Arboviruses and Leishmania chagasi
}

\author{
Gloria J Rey $/^{+}$, Cristina Ferro, Felio J Bello*
}

Instituto Nacional de Salud, Laboratorios de Virología y Entomología, Avenida El Dorado, Carrera 50, Santafé de Bogotá, D.C., Colombia *Universidad De La Salle, Departamento de Biología y Química, Carrera 2, No. 10-70,

Santafé de Bogotá, D.C., Colombia

Embryonic tissue explants of the sand fly Lutzomyia longipalpis (Lutz \& Neiva 1912) the main vector of Leishmania chagasi (Cunha and Chagas), were used to obtain a continuous cell line (Lulo). The tissues were seeded in MM/VP12 medium and these were incubated at $28^{\circ} \mathrm{C}$. The first subculture was obtained 45 days after explanting and 96 passages have been made to date. Lulo is composed of epithelioid cells, showed a 0.04 generations/hour exponential growth rate and population doubling time at $24.7 \mathrm{~h}$. The cell line isoenzymatic profiles were determined by using PGI, PGM, MPI and 6-PGDH systems, coinciding with patterns obtained from the same species and colony's pupae and adults. The species karyotype characteristics were recognized $(2 n=8)$, in which pair 1 is subtelocentric and pairs 2, 3 and 4 are metacentric. Lulo was free from bacterial, fungal, mycoplasmic and viral infection. Susceptibility to five arbovirus was determined, the same as Lulo interaction with Leishmania promastigotes.

Key words: arbovirus - cell line - characterization - Lutzomyia longipalpis - phlebotomine

Lutzomyia longipalpis is the main vector of Leishmania chagasi, the etiologic agent of American visceral leishmaniasis (Grimaldi et al. 1989, Grimaldi \& Tesh 1993). In the Americas, this Lutzomyia species extends from Mexico to Argentina (Young \& Duncan 1994); in Colombia it is found mainly in the Magdalena valley where it is often associated with endemic peridomiciliar foci of Le. chagasi in the Departments of Huila, Tolima, Cundinamarca and Santander (Corredor et al. 1990, Ferro et al. 1995). The only established cell line for these phlebotomines corresponds to that developed by Tesh and Modi (1983), LL-5, from $L u$. longipalpis insects collected in Brazil.

Though sand flies are better known as the vectors of Leishmania, these insects have also been implicated as vectors of Bartonella bacilliformis and of several arboviruses (Tesh \& Guzmán 1996). Concerning this last aspect, the works done by Tesh et al. (1986, 1987, 1989), on isolation and virus

This work was financed jointly by Colciencias (grant 1243-04-179-95), the Colombian National Institute of Health and La Salle University.

${ }^{+}$Corresponding author. Fax: (57-1) 2220401. E-mail: grey@hemagogus.ins.gov.co

Received 17 May 1999

Accepted 26 October 1999 identification, obtained from naturally infected phlebotomine sand flies (Lutzomyia spp.), collected in Colombia and other tropical American countries, are of particular importance.

Continuous lines of insect cells have played a special role in virology. The susceptibility of these cultures to different viruses of medical interest has been studied (Tesh 1979), viruses have been isolated and identified (Varma et al. 1976) and they have been adopted in substrates in the production of viral antigens (Hummel et al. 1992). Furthermore, they have helped in understanding cellular biology (Hink 1979) and, recently, they have provided information concerning molecular studies and biological control mechanisms (Yuval \& Warburg 1989).

The first insect cell line was established by Grace (1966); since then many different cell lines have been obtained, mainly corresponding to the orders Diptera, Lepidoptera, Hemiptera and Orthoptera. When initiating insect cell cultures, a general methodology similar to that employed in the establishment of mammalian cell cultures was used (Hsu et al. 1972); however, particular conditions need to be modified and standardized for each species depending upon the tissue selected for initial explant, culture media, additional nutritional supplements, $\mathrm{pH}$, incubation temperature and cell removal mechanisms, among others (Freshney 1987). 
In this paper, the establishment of a $L u$. longipalpis cell line is reported, originating from embryonic tissue collected from biological material in Colombia. Morphological, cytogenetical and biochemical characteristics, as well as susceptibility to arbovirus infection and interaction with Leishmania promastigotes, were also studied.

\section{MATERIALS AND METHODS}

Obtaining biological material-Lu. longipalpis immature forms (embryonated eggs and first stage larvae) were taken from the colony established in the Colombian National Institute of Health, Laboratory of Entomology; this colony was established with specimens collected from El Callejón near the town of Ricaurte in the Cundinamarca Department, Colombia $\left(4^{\circ} 18^{\prime} \mathrm{N}, 74^{\circ} 42^{\top} \mathrm{W}\right)$, in December, 1994. Groups of 100 females, after being fed on an anaesthetised hamster at the same time, were placed in a breeding jar which had been previously prepared with dental plaster of Paris at the bottom to allow oviposition. In turn, the jars were placed inside a polystyrene box to maintain constant environmental temperature and humidity conditions.

Eggs washing and disinfection - Embryonated eggs, having five to six days of incubation, were put separately into $50 \mathrm{ml}$ centrifuge tubes, kept in water until disinfected following the procedure described by Tesh (1980).

Obtaining larvae - Once the eggs were disinfected, they were placed in a previously sterilized Petri dish, having a filter-paper base wetted with 8-15 ml sterilised water; they were protected from the light using aluminium foil and incubated at $28^{\circ} \mathrm{C}$. Hatching began after $24 \mathrm{~h}$ of incubation.

Initiation of primary cultures - Sterile embryonated eggs were rinsed in MM/VP12 medium (Varma \& Pudney 1969); $1 \mathrm{ml}$ of egg mass was placed into a $2 \mathrm{ml}$ Ten Broek homogenizer where the eggs were disrupted mechanically. The resulting cell suspension was put into a $25 \mathrm{~cm}^{2}$ plastic cell culture flask which contained $5 \mathrm{ml}$ growth medium. It was incubated at $28^{\circ} \mathrm{C}$ and the culture was observed daily through an inverted microscope. Another option consisted of working with first stage larvae; after hatching, these were withdrawn from the Petri dish with entomological needles and placed on concavity microslides, where they were cut into 3-4 fragments being observed by stereoscope. They were then suspended in growth medium and placed in a plastic bottle in the same conditions as the eggs.

Subcultures - The first successful subculture was obtained in August, 1996, from 6 day old eggs, and 96 passages have been made to date. The breaking up of the confluent monolayers in the cultures was done mechanically with the help of a rubber policeman. The first four subcultures were carried out in a passage split ratio 1:2 at 45 day intervals. The time was gradually decreased until seven day intervals were reached with a 1:5 pass proportion and the FBS concentration was reduced to 5\%.

Morphological characteristics - Cell morphology was photographed and described from the culture observation, using an inverted microscope with phase contrast and an "Olympus" microphotographic system in increments of 100 to $400 \mathrm{X}$ magnification.

Sterility tests - Tests were carried out on the cell cultures to remove the possibility of bacteria, fungus or mycoplasma contamination (modification of the bisbenzimide technique as described by Russell et al. 1975). Finally, to show that the cultures were free from virus infection, a cell suspension was prepared from a bottle of 7-day incubation culture and kept frozen at $-70^{\circ} \mathrm{C}$ for a week. It was then thawed and quickly refrozen twice to be later centrifuged at 3,000 rpm for $5 \mathrm{~min}$. A total of 20 nursing mice were inoculated intracerebrally with $0.1 \mathrm{ml}$ of the supernatant and $0.1 \mathrm{ml}$ was also inoculated into each one of 20 tubes of Vero cells. The mice were observed for 28 days in the animal house and the Vero cells were observed for 15 days at $37^{\circ} \mathrm{C}$ through the inverted microscope.

Preservation of cell line - A cell suspension was prepared which contained $3-5 \times 10^{6} \mathrm{cell} / \mathrm{ml}$ in freezing medium (70\% MM/VP12, 20\% FBS and $10 \%$ DMSO) and was dispensed in one $\mathrm{ml}$ units into cryovials, stored at $-196^{\circ} \mathrm{C}$.

Cell growth measurement - The procedure described by McAteer and Davis (1994) was applied to determine the multiplication rate (r) and the Lulo Population Doubling Time (PDT), between passages 38 to 40 .

Cytogenetics - The procedure described by Schneider (1987) was carried out on a culture seeded $72 \mathrm{~h}$ before.

Isoenzymatic profiles - The isoenzymatic phenotypes of four enzyme systems were examined: PGI, PGM, MPI and 6-PGDH. The isoenzymes were separated using electrophoresis on cellulose acetate, according to the procedure described by Brown and Knudson (1980). Cell samples were run simultaneously with $\mathrm{Lu}$. longipalpis pupae and adult extracts coming from the same colony. The isoenzymatic patterns from the present cell line were compared with the Aedes taeniorhynchus cell line (Bello et al. 1995) and also, in the PGI system, with LL-5 cell culture (Tesh \& Modi 1983).

Susceptibility to arbovirus - The susceptibility of Lulo to five arboviruses, listed in Table I, was determined in parallel with the AA C6/36 cell line (Igarashi 1978). Dilutions from $10^{-1}$ to $10^{-4}$ were prepared from each one of the viruses; two tubes 
of Lulo cells and two tubes of AA C6/36 were subsequently inoculated with $0.1 \mathrm{ml}$ of each dilution. They were left to incubate for five days at $28^{\circ} \mathrm{C}$. After this time had elapsed, the cells were broken away, washed twice with PBS and impressions were made in 18-well slides, which were fixed with cold acetone for $10 \mathrm{~min}$ to carry out indirect immunofluorescence (IIF). To this end, a 1:20 specific hyper-immune antibody dilution produced in mice was prepared and left to incubate on the slides for $1 \mathrm{~h}$ at $37^{\circ} \mathrm{C}$. Later the slides were washed three times with PBS, left to dry and mouse anti-IgG conjugate labelled with fluorescein (1:80 dilution in 1:10,000 Evans blue) was added to them. They were incubated for $30 \mathrm{~min}$ at $37^{\circ} \mathrm{C}$. Finally, the slides were washed twice with BFS and once with distilled water. The preparations were mounted in glycerine buffer and observed under epifluorescence microscopy.

Lulo interaction with Leishmania chagasi promastigotes - Bottles of $25 \mathrm{~cm}^{2}$ containing $48 \mathrm{~h}$ old culture monolayers were inoculated with $0.5 \mathrm{ml}$ of a Le. chagasi promastigote suspension (WR strain, kept in the Colombian National Institute of Health, Laboratory of Parasitology in Schneider's medium supplemented with 20\% FBS and $20 \mu \mathrm{g} /$ $\mathrm{ml}$ gentamicin sulphate, at a $\mathrm{pH}$ of 7.4) which contained a $3.4 \times 10^{5}$ parasite/ml concentration and it was complemented with a $5 \mathrm{ml}$ volume of MM/ VP12 medium; the bottles were incubated at $24^{\circ} \mathrm{C}$ for 7 days. This procedure was carried out with con- trols for cells (Lulo plus MM/VP12 only), and medium (Lulo plus Schneider's medium), and control for parasites (promastigotes plus Schneider's medium), all of them into independent $25 \mathrm{~cm}^{2}$ bottles.

\section{RESULTS}

Establishing the cell line - The original Lulo culture was initiated on the 12th of July 1996 from embryonated eggs that had been incubated for six days. Explanting was carried out after ten days; some cells then started to adhere to the surface of the culture flask. These started to slowly increase in number and gave origin to cells having different morphology. The third week after the explant had been carried out, the culture was fed weekly with $2 \mathrm{ml}$ of fresh culture medium. The first subculture was carried out on the 45th day, using a rubber policeman to remove the cells from the culture bottle surface and putting them into fresh culture medium in a 1:2 proportion. The Lulo cultures were initially composed of a heterogeneous cell population, being consistently elongated, spherical, irregular, small and presenting vesicles constituted by epithelioid cells. Some monolayers having fibroblastoid cells predominated in the first subcultures, while epithelioid cells were more numerous in others. In higher passages, there was greater cell morphology uniformity, epithelioid types being predominant (Figs 1, 2, 3). In some larval explants it was observed that cells began to appear towards the edges of the fragments but these

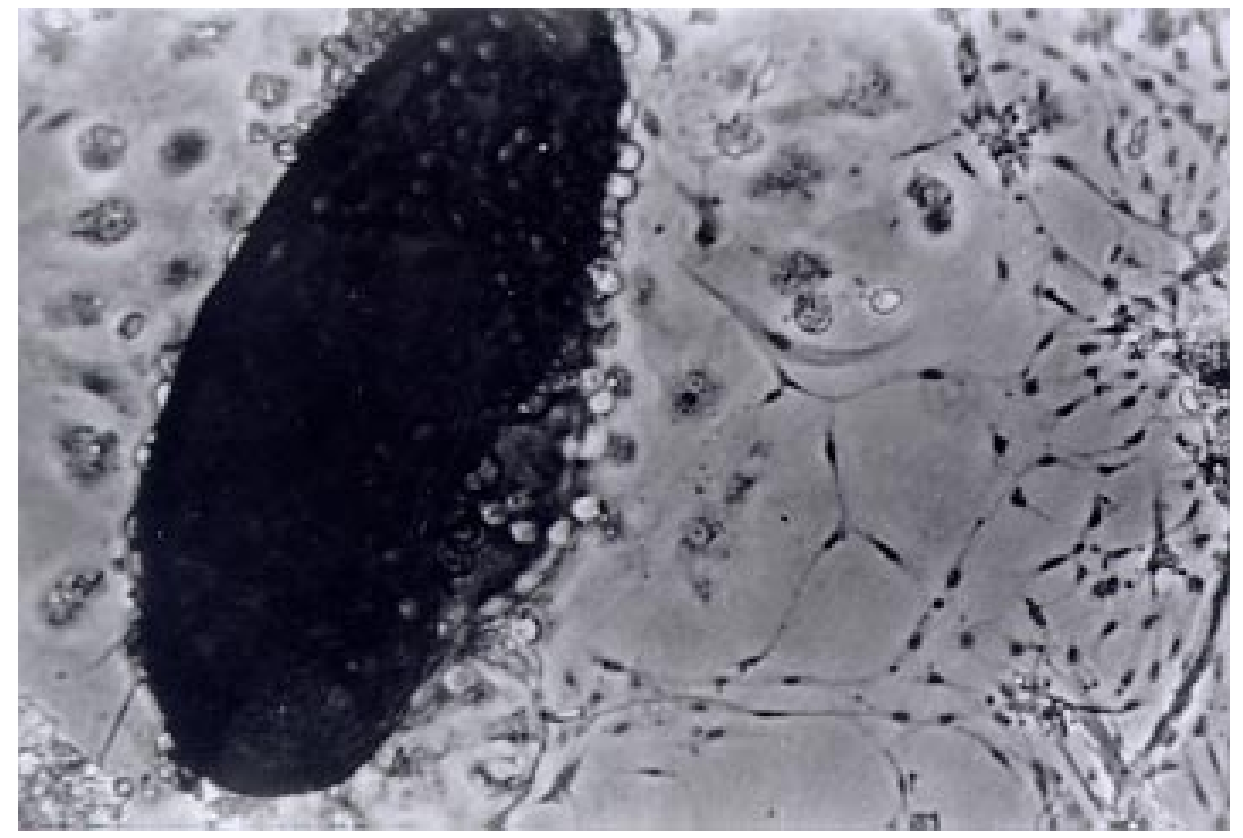

Fig. 1: migrating cells from Lutzomyia longipalpis egg explant. A fragmented egg having different cell growth types within and around it is observed. The cells having epithelioid morphology are located next to the egg, while fibroblastoid cells, having a greater migratory tendency, are found to be more removed from their site of origin. 


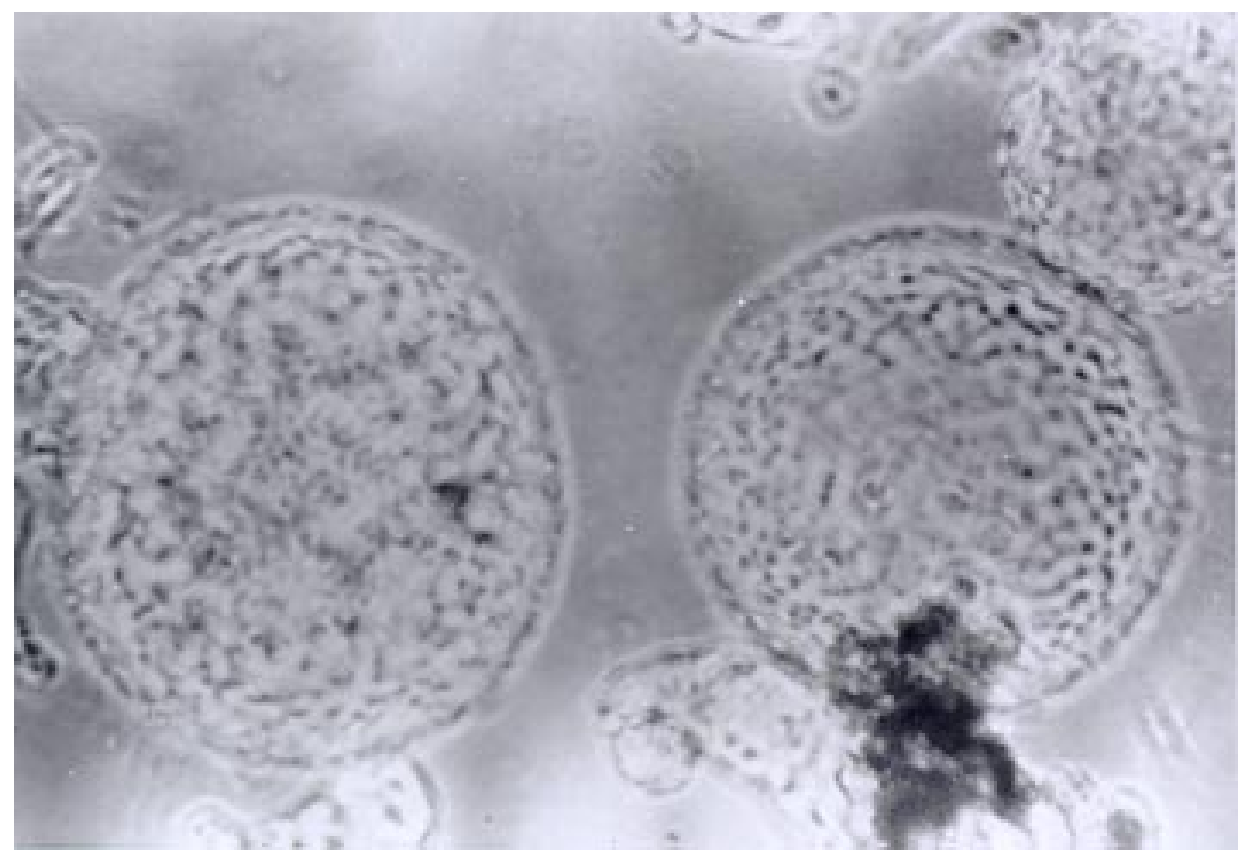

Fig. 2: different size vesicles formed by epithelioid cell aggregation around an empty space. These vesicles were produced in early Lulo subcultures.

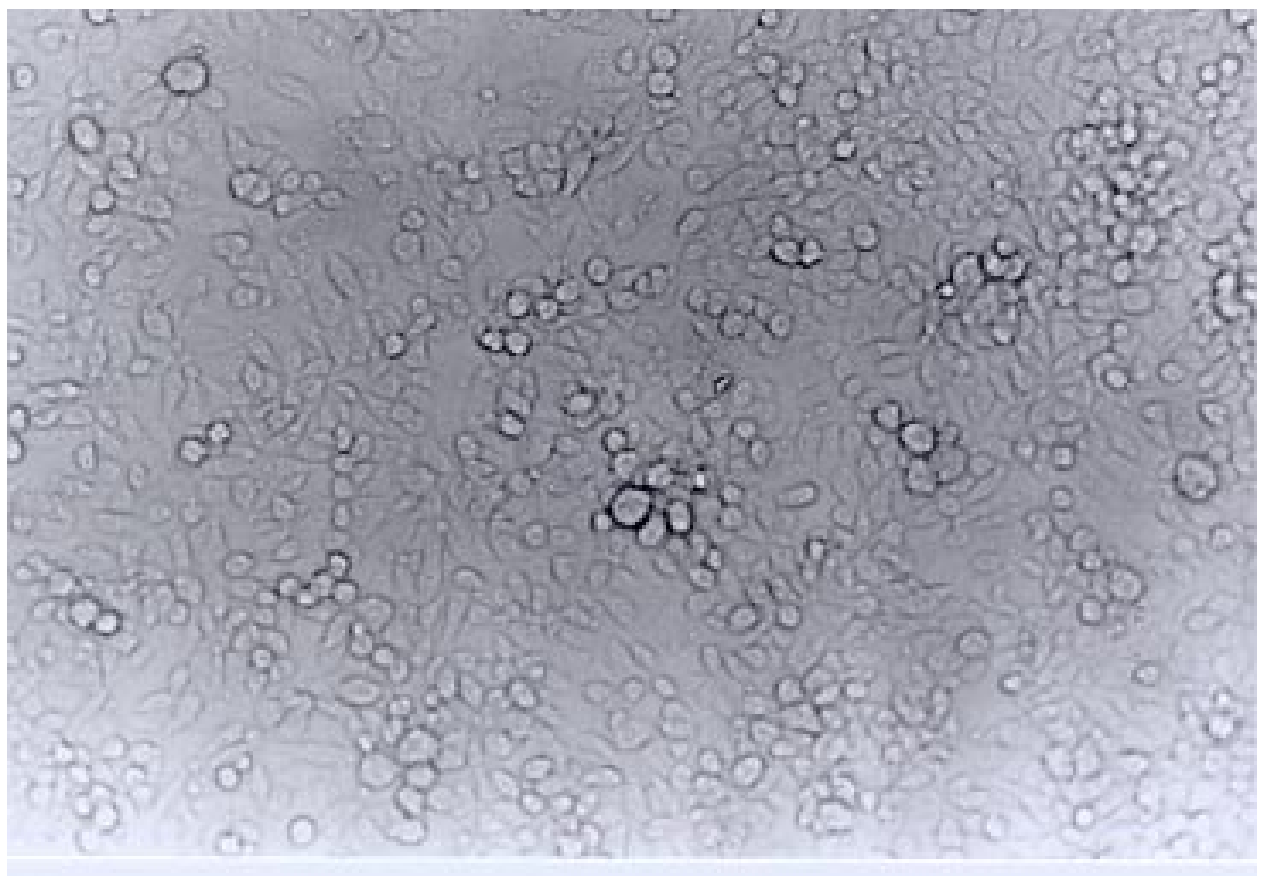

Fig. 3: confluent mono-layer Lutzomyia longipalpis cellular line epithelioid cells. At some sites, the cells began to overgrow and to form cell clusters or groups. 
were incapable of adapting to the medium and subsequently degenerated. After embryonic tissue explanting, the cells have been kept in MM/VP12 medium, with variations in FBS concentration; 20\% FBS during the first 12 subcultures, then the concentration was gradually reduced until $10 \%$ was reached after 20 passages had been made. The optimum $\mathrm{pH}$ range for cell growth in MM/VP12 medium was 6.7 to 6.9 and the average incubation temperature was $28^{\circ} \mathrm{C}$. The cells did not show bacterial, fungal, mycoplasmic nor viral contamination. The viability of frozen cells was shown at two weeks and at six months after being frozen. Thawing was carried out quickly, removing a vial from liquid nitrogen and plunging it immediately into a serological bath at $37^{\circ} \mathrm{C}$. The Lulo growth curve between passages 38 to 40 showed that there was one generation every $25 \mathrm{~h}$.

Karyotype characteristics - The metaphases obtained from cells corresponded to early subcultures and to the cell line, exhibiting a diploid number of eight chromosomes $(2 n=8)$, registering haploid, aneuploid and tetraploid presence, each one having a $5 \%$ frequency, while $85 \%$ were diploid. Chromosome pair one was classified as being subtelocentric, while pairs 2, 3 and 4 were metacentric.

Isoenzyme profiles - The isoenzymatic phenotypes of Lulo, corresponding to the four analyzed systems, were a band for PGI, PGM and 6-PGDH and two bands for MPI. These results also corresponded to the pupa and adult samples coming from the same species and colony. In Table II the average values for electrophoretic mobility relating to each one of the isoenzymatic systems of Lulo are shown, taking an Ae. taeniorynchus cell line as a pattern and also comparing the PGI system with the Lu. longipalpis (LL-5) cell line.

Arbovirus susceptibility - Lulo was sensitive to infection by three of the five inoculated arboviruses, representing the Togaviridae, Reoviridae and Rhabdoviridae families. The best replication capability was obtained using the Vesicular Stomatitis virus in the cell substrates which were used, while the Ilheus and Punta Toro viruses did not replicate in Lulo. None of the viruses which were examined produced cytopathic effects in the cultures (Table I).

Lulo interaction with Leishmania promastigotes - The parasites multiplied themselves in Lulo but in less quantity than that observed in Schneider's medium, however, they conserved motility and roseate formation characteristics. By contrast, after the fifth day of being in contact with parasites, the cells started to become round and to break away from the substrate, until cell death was finally produced towards the tenth day of incubation.

TABLE I

Arbovirus growth in insect cells

\begin{tabular}{|c|c|c|c|c|}
\hline \multirow[t]{2}{*}{ Family } & \multirow[t]{2}{*}{ Genus } & \multirow[t]{2}{*}{ Virus } & \multicolumn{2}{|c|}{ Cell line } \\
\hline & & & AA C6/36 & Lulo \\
\hline Togaviridae & Alfavirus & Mayaro & - & $+\left(10^{-3}\right)^{a}$ \\
\hline Flaviviridae & Flavivirus & Ileus & $+\left(10^{-2}\right)$ & - \\
\hline Reoviridae & Orbivirus & Changuinola & - & $+\left(10^{-2}\right)$ \\
\hline Bunyaviridae & Phlebovirus & Punta Toro & - & - \\
\hline Rhabdoviridae & Vesiculovirus & VSV & $+\left(10^{-3}\right)$ & $+\left(10^{-4}\right)$ \\
\hline
\end{tabular}

$a$ : greater virus dilution showing greater infection capacity.

TABLE II

Relative electrophoretic mobility for the four isoenzymes used in the study

\begin{tabular}{|c|c|c|c|c|c|}
\hline \multirow[t]{2}{*}{ System } & \multicolumn{2}{|c|}{ Lutzomyia longipalpis } & \multicolumn{3}{|c|}{ Cell lines } \\
\hline & Adults & Pupa & Lulo & Aedes $^{a}$ & LL- $5^{b}$ \\
\hline PGI & 58.10 & 58.53 & 58.73 & 100 & 53.16 \\
\hline PGM & 97.60 & 97.08 & 97.02 & 100 & \\
\hline 6-PGDH & 87.11 & 87.61 & 87.56 & 100 & \\
\hline \multirow[t]{2}{*}{ MPI } & 61.16 & 61.25 & 61.86 & 100 & \\
\hline & 47.90 & 40.18 & 40.00 & 64.18 & \\
\hline
\end{tabular}

a: Aedes taeniorhynchus (Bello et al. 1995); b: Lutzomyia longipalpis (Tesh 1983). 


\section{DISCUSSION}

The MM/VP12 medium with $20 \%$ FBS, at an incubation temperature of $28^{\circ} \mathrm{C}$ and a pH of 6.7 to 6.9 , provided the necessary environmental and nutritional conditions for explant survival and for new cell growth. Due to this, subcultures continued to be carried out in MM/VP12 medium, reducing the FBS concentration in greater passages to $5 \%$. Although the MM/VP12 medium was also used in the initiation of the LL-5 cell line (Tesh \& Modi 1983) the FBS concentration was kept at 15\% and the culture initiated with eggs laid 3-5 days before. Furthermore, differences were observed in the primary culture, while in LL-5 the primary adherent cells became evident 14 days after initiating explant and the first subculture was made on the 107th day, a weekly pass being made thereafter. The first adherent cells were obtained in Lulo 10 days after explant and their first subculture was carried out in less time (45 days), slowly diminishing the time required to establish pass frequency to a week, after the twentieth passage. The foregoing could be due to the particular characteristics of the Lu. longipalpis populations used; this being different to other subcultures obtained from Culex theileri (Oelofsen et al. 1990), Toxorhynchites amboinensis (Tesh 1980) and Anopheles gambiae (Marhoul \& Pudney 1972) mosquitoes which lasted for less time in similar conditions. Another difference between the two phlebotomine established cell lines was in the morphological characteristics of the culture; the Lulo cell line was composed of epithelioid cells, while the presence of two types of cells was reported in LL-5: some small epithelioids and some other bigger fibroblastoids.

The Lulo karyotype, whose diploid number was eight chromosomes, coincided with that reported for this species and was found to be within the observed range of $2 n=6$ to $2 n=10$ for phlebotomines from the Old and the New Worlds (Carvalho et al. 1962, Kreutzer et al. 1987, 1988). The morphological characteristics of the Lulo chromosomes showed pair one to be subtelocentric, while pairs 2, 3 and 4 were metacentric, there being little difference in size between pairs 3 and 4 . None of the four chromosome pairs showed heteromorphism. A low percentage of cells in metaphase was seen with $85 \%$ of the cells diploid and the remainder heteroploid, aneuploid and haploid. Lulo can thus be considered as a diploid cell line.

Isoenzymatic profiles coincided with pupa and adult samples in four different systems from the same species and the same colony, showing the origin of Lulo from the embryonic tissue of the insect. The comparison of this cell line in the PGI system with LL-5 from $L u$. longipalpis (originating from a colony established with material com- ing from Belo Horizonte, Brazil) gave different results. This suggests that, in cell cultures, the species (derived from two South American populations) could also present genetic polymorphism, sustaining the idea that it is a complex of species (Ward et al. 1983, Lanzaro et al. 1993, 1998).

Other interesting data provided by the study revealed that alphavirus (Mayaro) infected Lulo cells, while no evidence of infection was found in AA C6/36, in spite of the fact that positivity has been reported by Mezencio et al. (1989) in their experiments involving this cell clone; which could probably be due to a modification of the specific clone C6/36 cell employed in the present study. The results obtained with Punta Toro virus (phlebovirus) were unexpected, due to the fact that it did not produce infection in the Lulo cells nor in the AA C6/36 cell line, the same negative results having been described in LL- 5 by Tesh and Modi in 1983. The explanation could lie in the fact that the sand-fly is composed of different cell populations, while the established cell line generally contains a single cell population. For example, Igarashi et al. (1973) showed differences in the Japanese encephalitis virus' ability to replicate in Ae. aegypti cells; Igarashi also showed growth variations in chikungunya and dengue viruses in selected Ae. albopictus clones' cells. These observations suggest that for arbovirus growth, the type of predominant cell in the cell culture must be as important a factor as the species providing the origin of culture. Two of the three arbovirus isolated from phlebotomie sand flies (Changuinola and Vesicular Stomatitis), and used in cell culture infection demonstrated the ability to replicate in Lulo, suggesting that this cell line could be used for future indigenous virus isolation, associated with sand flies and, extensively, with other arthropod vectors, to be considered from the perspective of also supporting viral characterization studies at molecular level.

In the Lulo interaction with Leishmania promastigote assays, the fact that the parasites conserved their viability and could multiply themselves, was not due to the MM/VP12 medium, but rather to some type of relationship which the parasite established with the cell, perhaps taking some growth factors or ions from it, which (such as iron) are fundamental substances for parasite preservation (Wilson et al. 1994).

This preliminary description of the behavior of Le. chagasi linked to Lulo could be the starting point for vector-parasite development interaction studies in these cells. This will probably make in vitro development of their biological cycle possible (in spite of Leishmania being an extracellular parasite in the insect), when modifying some cell cul- 
ture physical-chemical factors; this situation will be achieved only after further experiments has been carried out to determine parasite differentiation and maturity. From the in vitro co-culturing system (i.e. Lulo with the parasite) research can be developed concerning Leishmania metabolism, anti-parasitic drug evaluation and antigen production which can be used in diagnostic tests and vaccines. These activities will constitute a great support for studies of parasite which is currently being carried out in other cell substrates derived from the tissues of humans and other mammals (Kiderlen et al. 1986, Vouldoukis et al. 1986, Carvalho et al. 1989, Konecny et al. 1999, Mukhopadhyay et al. 1999, Nandan et al. 1999).

Other potential Lulo applications could be presented at physiological and genetic investigation levels, in a similar way to those effected in other lines derived from insects (Leake 1997).

\section{ACKNOWLEDGEMENTS}

To Robert Tesh of the University of Texas Medical Branch, Department of Pathology, for his valuable collaboration with the donation of the virus and antisera used in this study.

\section{REFERENCES}

Bello F, Boshell J, Rey G, Morales A, Olano V 1995. Initiation of primary cell cultures from embryos of the mosquitoes Anopheles albimanus and Aedes taeniorhynchus (Diptera: Culicidae). Mem Inst Oswaldo Cruz 90: 547-551.

Brown S, Knudson D 1980. Characterization of invertebrate cell lines. In Vitro 16: 829-832.

Carvalho de H, Falcão A, Schreiber G 1962. Cariotipo dos Phlebotomus. Ciênc Cult 14: 38.

Carvalho EM, Bacellar O, Barral A, Badaró R, Johnson WD Jr 1989. Antigen specific immunosuppression in visceral leishmaniasis is cell mediated. J Clin Invest 83: 860-864.

Corredor A, Kreutzer R, Tesh R, Boshell J, Palau M, Cáceres E, Duque S, Peláez D, Rodriguez G, Nicholls S, Hernández C, Morales A, Ferro de Carrasquilla C 1990. Distribution and etiology of leishmaniasis in Colombia. Am J Trop Med Hyg 42: 206-214.

Ferro C, Pardo R, Torres M, Morrison A 1995. Larval microhabitats of Lutzomyia longipalpis (Diptera: Psychodidae) in an endemic focus of visceral leihmaniasis in Colombia. J Med Entomol 34: 719728.

Freshney R 1987. Culture of Animal Cells. A Manual of Basic Technique, 2nd ed., Wiley-Liss, New York, $397 \mathrm{pp}$.

Grace T 1966. Establishment of a line of mosquito (Aedes aegypti L.) cells grown in vitro. Nature 211: 366367.

Grimaldi G, Tesh R 1993. Leishmaniases of the New World: current concepts and implications for future research. Clin Microb Rev 6: 230-250.

Grimaldi G, Tesh R, McMahon-Pratt D 1989. A review of the geografic distribution and epidemiology of leishmaniasis in the New World. Am J Trop Med Hyg 41: 687-725.

Hink W 1979. Cell lines from invertebrates. In W Jakoby \& I Pastan (eds), Methods in Enzimology, Vol. LVII, Academic Press, San Diego, USA, p. 450-466.

Hsu S, Li S, Cross J 1972. A cell line derived from ovarian tissue of Culex tritaeniorhynchus summorosus Dyar. J Med Entomol 9: 86-91.

Hummel K, Erdman D, Heath J, Bellini W 1992. Baculovirus expression of the nucleoprotein gene of measles virus and utility of the recombinant protein in diagnostic enzyme immunoassays. J Clin Microbiol 30: 2874-2880.

Igarashi A 1978. Isolation of Singh's Aedes albopictus cell clone sensitive to dengue and chikungunya viruses. J Gen Virol 40: 531-544.

Igarashi A, Sasao F, Wungkobkiat S, Fukai K 1973. Growth of Japanese encephalitis virus in established lines of mosquito cells. Biken J 16: 17-23.

Kiderlen AF, Baccarini M, Lohmann Matthes ML 1986. A fast and objetive assay for cell mediated intra and extracellular killing of Leishmania promastigotes. $J$ Immunol Methods 86: 199-203.

Konecny P, Stagg AJ, Jebbari H, English N, Davidson RN, Knight SC 1999. Murine dendritic cells internalize Leishmania major promastigotes, produce IL$12 \mathrm{p} 40$ and stimulate primary T cell proliferation in vitro. Env J Immunol 29: 1803-1811.

Kreutzer R, Morales A, Cura E, Ferro C, Young D 1988. Brain cell karyotypes of six new world sand flies (Diptera: Psychodidae). J Am Mosq Cont Ass 4: 453455.

Kreutzer R, Modi G, Tesh R, Young D 1987. Brain cell karyotypes of six species of New and Old World sand flies (Diptera: Psychodidae). J Med Entomol 24: 609-612.

Lanzaro G, Alexander B, Mutebi J, Montoya-Lerma J, Warburg A 1998. Genetic variation among natural and laboratory colony populations of Lutzomyia longipalpis (Lutz \& Neiva 1912) (Diptera: Psychodidae) from Colombia. Mem Inst Oswaldo Cruz 93: 65-69.

Lanzaro G, Ostrovska K, Herrero M, Lawyer P, Warburg A 1993. Lutzomyia longipalpis is a species complex: Genetic divergence and inter-specific hybrid sterility among three populations. Am J Trop Med Hyg 48: 839-847.

Leake CJ 1997. Establishing primary cell cultures from disease vectors and maintenance of continuous cell lines. In JM Crampton, CB Beard \& C Louis (eds), The Molecular Biology of Insect Disease Vectors, Chapman \& Hall, London, p. 487-499.

Marhoul Z, Pudney M 1972. A mosquito cell line (Mos. 55) from Anopheles gambiae larvae. Trans $R$ Soc Trop Med Hyg 66: 183-184.

McAteer J, Davis J 1994. Basic cell culture technique and the maintenance of cell lines. In J Davis, Basic Cell Culture. A practical Approach, Oxford University Press Inc., New York, p. 93-148.

Mezencio JM, de Souza W, Fonseca ME, Rebello MA 1989. Replication of Mayaro virus in Aedes 
albopictus cells: an electron microscopic study. Arch Virol 104: 299-308.

Mukhopadhyay S, Sen P, Bhattacharyya S, Majumdar S, Ray S 1999. Immunoprophylaxis and immunotherapy against experimental visceral leismaniasis. Vaccine 17: 291-300.

Nandan D, Lo R, Reiner NE 1999. Activation of phosphotyrosine phosphatase activity attenuates mitogen-activated protein kinase signaling and inhibits c-FOS and nitric oxide synthase expression in macrophages infected with Leishmania donovani. Infect Immun 67: 4055-4063.

Oelofsen M, Gericke A, Smith M, De K Van der Linde T 1990. Establishment and characterization of a cell line from the mosquito Culex (Culex) theileri (Diptera: Culicidae) and its susceptibility to infection with arboviruses. J Med Entomol 27: 939-944.

Russell W, Newman C, Williamson D 1975. A simple cytochemical technique for demonstrations of DNA in cells infected with mycoplasmas and viruses. Nature 2: 461-462.

Schneider I 1987. Preparation and maintenance of arthropod cell cultures: Diptera, with emphasis on mosquitoes. In CE Yunker, Arboviruses in Arthropod Cells in Vitro, Vol. 1., CRC Press, Boca Ratón, Fl, p. 31.

Tesh R, Guzman H 1996. Sand flies and the agents they transmit. In BJ Beaty \& WC Marquardt (eds), The Biology of Disease Vectors, University Press of Colorado, USA, p. 117-127.

Tesh R, Boshell J, Young D, Morales A, de Carrasquilla C, Corredor A, Modi G, Travassos da Rosa APA, McLean R, de Rodríguez C, Gaitan M 1989. Characterization of five new phleboviruses recently isolated from sand flies in tropical America. Am J Trop Med Hyg 40: 529-533.

Tesh R, Boshell J, Modi G, Morales A, Young D, Corredor A, Ferro C, de Rodriguez C, Walters L, Gaitán M 1987. Natural infection of humans, animals, and phlebotomine sand flies with the Alagoas serotype of vesicular stomatitis virus in Colombia. Am J Trop Med Hyg 36: 653-661.

Tesh R, Boshell J, Young D, Morales A, Corredor A, Modi G, Ferro C, de Rodriguez C, Gaitán M 1986. Biology of Arboledas virus, a new phlebotomus fever serogroup virus (Bunyaviridae: Phlebotovirus) isolated from sand flies in Colombia. Am J Trop Med Hyg 35: 1310-1316.

Tesh R, Modi G 1983. Development of a continuous cell line from the sand-fly Lutzomyia longipalpis (Diptera: Psychodidae), and its susceptibility to infection with arboviruses. J Med Entomol 20: 199-202.

Tesh R 1980. Establishment of two cell lines from the mosquito Toxorhynchites amboinensis (Diptera: Culicidae) and their susceptibility to infection with arboviruses. J Med Entomol 17: 338-343.

Tesh R 1979. A method for the isolation and identification of dengue viruses, using mosquito cell cultures. Am J Trop Med Hyg 28: 1053-1059.

Varma M, Pudney M, Leake C, Peralta P 1976. Isolations in a mosquito (Aedes pseudoscutellaris) cell line (Mos 61) of yellow fever virus strains from original field material. Intervirology 6: 50-56.

Varma M, Pudney M 1969. The growth and serial passage of cell lines from Aedes aegypti (L.) larvae in different media. J Med Entomol 6: 432-439.

Vouldoukis I, Alfred C, Monjour L, Mazier D, Brandicourt O, Ploton I, Tselentis Y, Nzuzi KK, Gentilini M 1986. Culture systems for production of promastigote and amastigote forms of Leishmania application to serological diagnosis and therapeutic trials. Ann Parasitol Hum Comp 61:147-154.

Ward R, Ribeiro A, Ready P, Murtagh A 1983. Reproductive isolation between different forms of Lutzomyia longipalpis (Lutz and Neiva), (Diptera: Psychodidae), the vector of Leishmania donovani Chagas/Cunha and Chagas and its significance to Kala-Azar distribution in South America. Mem Inst Oswaldo Cruz 78: 269-280.

Wilson M, Vorhies R, Andersen K, Britigan B 1994. Acquisition of iron from transferrin and lactoferrin by the protozoan Leishmania chagasi. Infect Immun 62: 3262-3269.

Young D, Duncan M 1994. Guide to identification and geografic distribution of Lutzomyia and sand-flies in Mexico, West Indies, Central and South America (Diptera: Psychodidae). Mem Amer Entomol Inst 54: 1-881.

Yuval B, Warburg A 1989. Susceptibility of adult phlebotomine sandflies (Diptera: Psychodidae) to Bacillus thuringiensis var. israeliensis. Am Trop Med Parasitol 83: 195-196. 